J. Clin. Chem. Clin. Biochem.

Vol. 17, 1979, pp. 541-545

\title{
Two-Dimensional Electrophoretic Analysis of Ribosomal Proteins from Chronically Injured Liver
}

\author{
By A.M. Gressner \\ Department of Clinical Chemistry and Pathobiochemistry of the Medical Faculty of the RWTH, Aachen, FRG
}

(Received September 29, 1978/January 25, 1979)

\begin{abstract}
Summary: Proteins of the small and large ribosomal subunit, isolated at various times from long-term thioacetamidedamaged rat livers, were analysed by two-dimensional polyacrylamide gel electrophoresis and compared with those from normal liver.

Chronic hepatic injury induced a number of time-dependent changes of the structural proteins of the small subunit, whereas the proteins of the large subparticle were essentially unaffected. The most significant alterations were an anodical dislocation of protein S6, a strong diminution in the amounts of proteins S9 and S10 and the occurrence of 3 to 4 additional small subunit proteins.
\end{abstract}

By autoradiographic studies it was established that the modifications of S6 were brought about by an enhanced phosphorylation of this protein, which was the earliest sign of a ribosomal alteration in injured liver tissue.

\section{Zwei-dimensional elektrophoretische Untersuchungen ribosomaler Proteine der chronisch geschädigten Leber}

Zusammenfassung: Proteine der kleinen und großen ribosomalen Untereinheit wurden zu verschiedenen Zeitpunkten aus langfristig mit Thioacetamid geschädigten Rattenlebern isoliert und nach Auftrennung in der zwei-dimensionalen Poly acrylamidgel-Elektrophorese mit ribosomalen Proteinen aus der normalen Leber verglichen.

Chronische Leberschädigung induziert mehrere, zeitabhängige Veränderungen der Strukturproteine der kleinen Untereinheit, wohingegen diejenigen der großen Subfraktion im wesentlichen unverändert bleiben. Die bedeutsamsten Alterationen sind eine anodische Verlagerung des Proteins S6, eine starke Verminderung der Mengen der Proteine S9 und $\mathrm{S} 10$ sowie 3 bis 4 zusätzliche Proteine der kleinen ribosomalen Untereinheit.

Durch autoradiographische Untersuchungen wurde festgestellt, daß die Modifikation des Proteins S6 durch eine erhöhte Phosphorylierung bedingt ist, welche gleichzeitig das früheste Zeichen einer ribosomalen Alteration in dem geschädigten Lebergewebe darstellt.

\section{Introduction}

Eukaryotic ribosomes are composed of approximately 70 unique proteins (about 30 in the small subparticle and 40 in the large) and 3 molecular species of RNA (1). Recent reports on their structure and function have provided evidence for a dynamic rather than a static composition of these proteinsynthesizing organelles $(2,3,4)$. The structure of the mature ribosomes can be altered postsynthetically by enżymatic modifications, additions and deletions of individual ribosomal proteins or by cyclic changes of their conformations (5). The variations of the architecture of the ribosomes probably will have a number of functional effects either on the activity of the particle in translating all or certain species of mRNA, on their behaviour in the ribosome cycle, or on some other ribosomal functions such as binding to the membranes.

Both human $(6,7,8)$ and experimental $(9,10,11,12)$ liver diseases are accompanied by qualitative as well as quantitative changes of hepatic protein synthesis. This is clearly exemplified in long-term liver injury (13) leading to fibrosis and cirrhosis by an enhanced ribosomal production of collagen (14) and of the protein moiety of proteoglycans (15), whereas the synthesis of noncollagenous proteins remains nearly unaffected (16). The cell types competent for the production of these and 
other specific proteins, and the factors regulating, at a molecular level, their rates of synthesis in the damaged tissue are only poorly understood. Therefore additional information regarding the structural composition of the ribosomal organelles may eventually result in the increased discernment of mechanisms operating improperly in the diseased state.

The present studies were designed to determine whether modifications occur in the liver ribosomal protein components during chronic hepatic injury. The twodimensional electrophoresis technique (17) affords an excellent opportunity to make qualitative examinations of these proteins.

\section{Materials and Methods}

\section{Treatment of rats}

Male Sprague-Dawley rats ( 250 to $300 \mathrm{~g}$ initial body weight) were fed with a standard rat diet and tap water containing 4 $\mathrm{mmol} / \mathrm{l}$ of thioacetamide (15). Control rats received water without thioacetamide. The induction of chronic hepatic injury was proven by histological examinations as reported previously (15).

\section{Preparation of ribosomal particles and ribosomal proteins}

One week, 1, 2, 3, and 4 months after the beginning of the treatment one control rat and two thioacetamide treated rats, respectively, were sacrificed, their livers were quickly removed, chilled in ice-cold buffer $\mathrm{A}(0.05 \mathrm{~mol} / \mathrm{l}$ Tris- $\mathrm{HCl}, \mathrm{pH} 7.6$ at $20^{\circ} \mathrm{C}, 0.08 \mathrm{~mol} / \mathrm{KCl}, 0.0125 \mathrm{~mol} / 1 \mathrm{MgCl}_{2}, 0.25 \mathrm{~mol} / \mathrm{l}$ sucrose) and ribosomes were prepared (18). Small and large subunits were separated (fig. $1 \mathrm{a}$ ) on linear $0.3-0.9 \mathrm{~mol} / 1$ sucrose gradients in high ionic strength buffer (19), dialyzed against buffer $A$ and precipitated with ethanol (20). The $60 \mathrm{~S}$ subunit fraction was resolved further by recentrifugation (fig. $1 \mathrm{~b}$ ) to free it of contamination with $40 \mathrm{~S}$ subunits.

Ribosomal proteins were extracted from the subunits with acetic acid (21) and their concentrations were determined (22) using bovine serum albumin as a standard.

\section{Two-dimensional polyacrylamide gel electrophoresis of} ribosomal proteins

About $540 \mu \mathrm{g}$ and $620 \mu \mathrm{g}$ of ribosomal proteins extracted from the $40 \mathrm{~S}$ and $60 \mathrm{~S}$ subunits, respectively, were separated by the modified (23) Kaltschmidt-Wittmann technique (17)
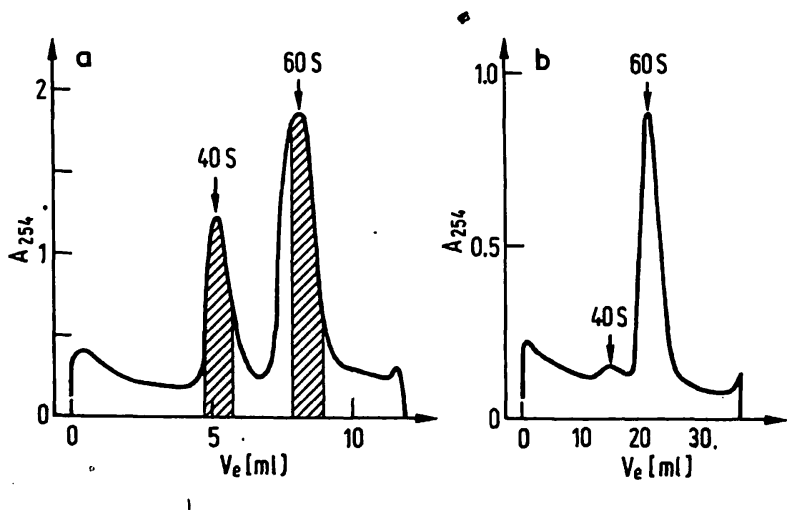

Fig. 1. Separation of small $(40 \mathrm{~S})$ and large $(60 \mathrm{~S})$ ribosomal subunits from liver by centrifugation $(4.5 \mathrm{~h}, 96000 \mathrm{~g}$, $26^{\circ} \mathrm{C}$ ) through a $0.3-0.9 \mathrm{~mol} / 1$ sucrose gradient. The hatched areas of the peaks were collected

a) separation profile of $80 \mathrm{~S}$ ribosomes

b) profile obtained after recentrifugation of the $60 \mathrm{~S}$ fraction of bidimensional electrophoresis on small polyacrylamide gel slabs Individual ribosomal proteins were numbered according to the nomenclature of Sherton \& Wool (24).

\section{Autoradiography of ribosomal proteins}

Ribosomal proteins were isolated from the livers of rats which received i.p. $30 \mathrm{~min}$ before exitus $37 \mathrm{MBq} \triangleq 1 \mathrm{mCi}$ of carrierfree $0-\left({ }^{32} \mathrm{P}\right)$-phosphoric acid (New England Nuclear Corp., Boston, USA) and subjected to analysis by bi-dimensional electröphoresis. The gel-slabs were dried and exposed to Kodak Kodirex X-ray film as described elsewhere (26).

\section{Results}

Proteins of the small (40 S) and large (60 S) ribosomal subunits were analysed separately. Since the electrophoretic procedure used excludes the examination of acidic components (23) only basic proteins of each subunit will be considered in the present study.

\section{Proteins of the $40 \mathrm{~S}$ subunit}

The 2-dimensional electrophoretic patterns of liver ribosomal proteins change significantly during thioacetamide-induced chronic hepatic injury (fig. 2). One week after the beginning of the treatment an anodical shift of protein S6, leading to an elongated shape, was observed (fig. 2 B). The modified portion (S6p) migrates both in the first and second dimension more slowly than the protein isolated from a healthy liver (fig. 2 A). The anodical extension of $\$ 6$ was noted, albeit to a smaller degree, in all stages of chronic liver injury (fig. $2 \mathrm{C}-\mathrm{F}$ ). In addition to this finding a strong diminution in the amount of protein $\mathrm{S} 9$ leading to its absence from the electrophoretograms was noticeable during the first 4 weeks of liver damage (fig. $2 \mathrm{~B}, \mathrm{C}$ ). Later, protein $\mathrm{S} 9$ was recovered in physiological amounts, whereas protein $\mathrm{S} 10$ was not discernible in advanced stages ( 1 to 4 months) of long-term injury ( $d$ in fig. 2 D). After 2 months of hepatic damage 4 proteins not seen in small ribosomal subunits from normal liver became visible: two proteins ( $a, b$ in fig. $2 \mathrm{D}$ ) could be separated from S3 and S7 because of their faster mobility during the run in the first dimension; one additional protein (e in fig. 2 D) was located cathodically relative to $S 14$ in the second dimension; a portion of protein S6 (c in fig. 2D) migrated faster in both dimensions than the unchanged part of this protein thus giving the impression of a cathodically located satellite-protein of S6. The additional proteins described were detectable in ribosomal preparations from livers injured for up to 4 months with thioacetamide.

Since it was reported recently that liver ribosomes can be phosphorylated in vivo $(25-28)$ autoradiographic studies were performed to see whether this type of modification of ribosomal proteins is effective also in chronically injured livers. Radioautographs demonstrate that in normal liver (fig. $3 \mathrm{~B}$ ) only a single protein (S6) incorporates radioactive phosphate, a process which 


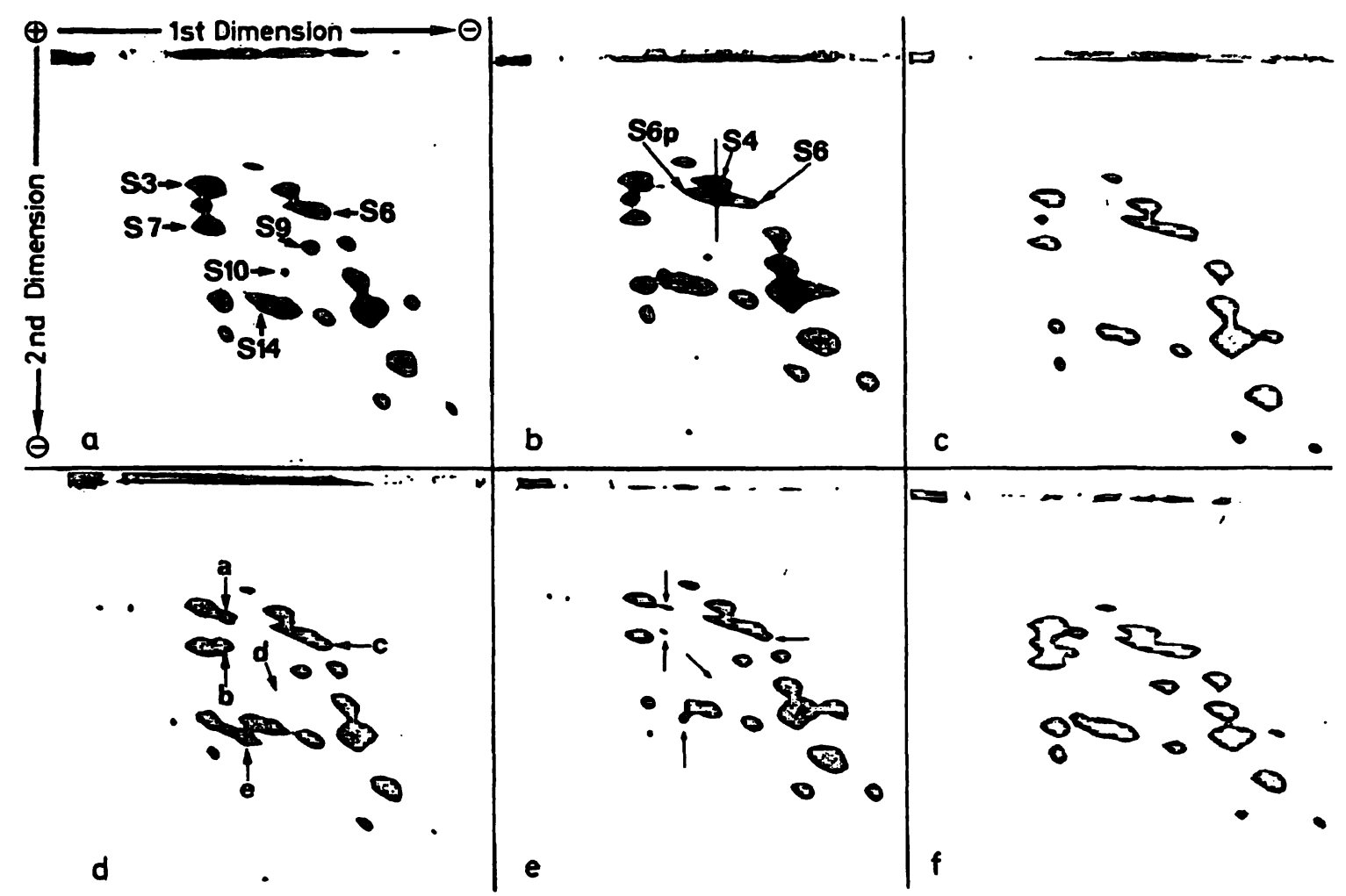

Fig. 2. Two-dimensional polyacrylamide gel electrophoretograms of $40 \mathrm{~S}$ ribosomal subunit proteins from normal rat liver (A) and liver injured for 1 week (B), 1 (C),2 (D),3 (E), and 4 (F) months with thioacetamide. In (B) a vertical line was constructed through the center of protein S4 to demonstrate the anodical shift of protein S6p. The proteins were designated according to Sherton \& Wool (24), the most significant changes in (B) to (F) are indicated by arrows and small letters.

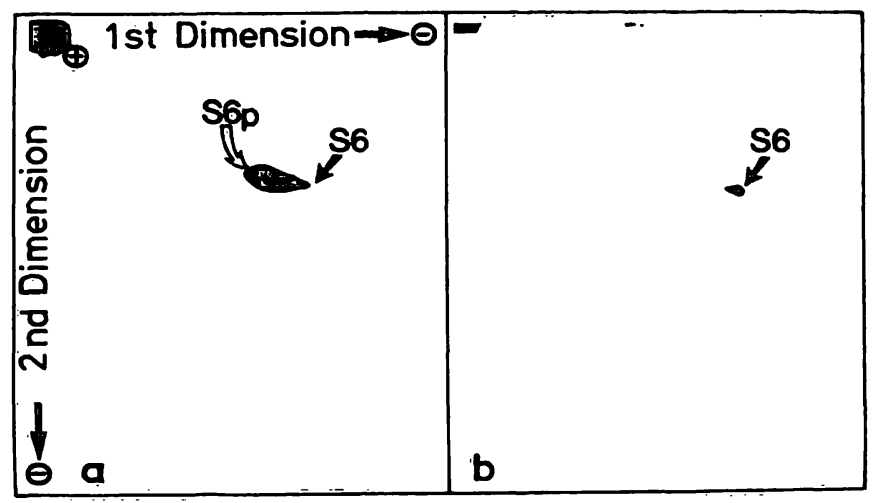

Fig. 3. Radioautographs of ( $\left.{ }^{32} \mathrm{P}\right)$-labeled $40 \mathrm{~S}$ ribosomal protein from normal (B) and 1 week-injured (A) rat liver separated by two-dimensional gel electrophoresis. The procedure was the same as in fig. 2. The positions of protein $\$ 6$ and of its phosphorylated derivative S6p are indicated.

was found to be significantly enhanced in the early stages of chronic liver damage (fig. $3 \mathrm{~A}$ ). Thus the occurrence of the modified portion (S6p) of protein S6 (fig. 2 B), which had a reduced electrophoretic mobility, is due to a higher degree of phosphorylation increasing the negative charge of the protein. No additional ribosomal phosphoprotein could be observed under the experimental conditions (fig. 3 ).

\section{Proteins of the $60 \mathrm{~S}$ subunit}

The electrophoretic patterns of $60 \mathrm{~S}$ liver ribosomal proteins obtained at various times of chronic hepatic damage reveal that there were no significant changes of any of the 40 basic proteins of this subunit (fig. 4). Even after 4 months of injury (fig. $4 \mathrm{D}$ ), fingerprints of ribosomal proteins remained congruent with those from healthy liver (fig. $4 \mathrm{~A}$ ).

\section{Discussion}

Two-dimensional electrophoretograms reveal that several time-dependent changes of the protein composition of the small but not of the large liver ribosomal subunit take place during the development of chronic hepatic injury. The striking diminution in the relative amounts of proteins $\mathrm{S} 9$ and $\mathrm{S} 10$ might result from an impairment of either their synthesis or their incorporation into the particle. Since liver cytosol contains little if any free ribosomal proteins (25) the latter mechanism would increase the amounts of proteins $S 9$ and $\mathrm{S} 10$ in the cytosol. Immunochemical analysis provides a powerful technique to test this interesting possibility in diseased liver.

It is likely that the occurrence of additional polypeptides (S6p, a, b, c, e in fig. 2 D) is due to chemical derivatization 


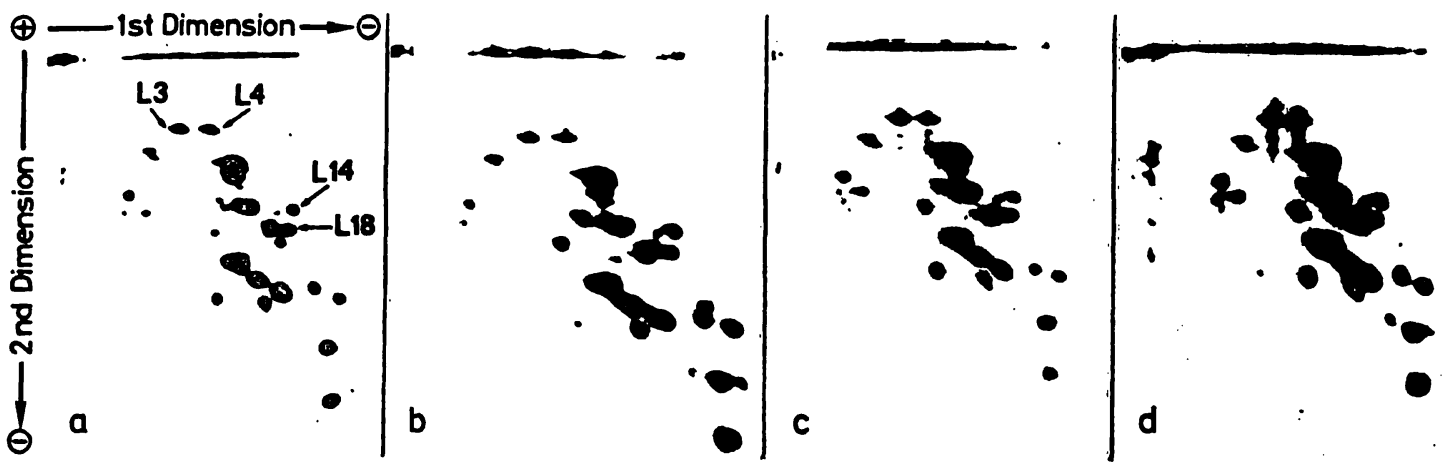

Fig. 4. Two-dimensional polyacrylamide gel electrophoretograms of $60 \mathrm{~S}$ ribosomal subunit proteins from normal rat liver (A) and liver injured for 1 week (B),3 (C), and 4 (D) months with thioacetamide. Some proteins are indicated by numbers (24).

of some as yet unidentified proteins, to produce forms with different electrophoretic mobilities. Since structural ribosomal proteins can be modified in vivo by reversible phosphorylation (26-32), acetylation (3335 ) or methylation (36-39), further work is required to establish both the effectiveness of the enzymatic modifications in chronic liver injury and the homologies between the derivatives (isoproteins) and the unmodified "mother"-proteins. Both questions have been solved with regard to $\mathrm{S6}$ which was shown in the present and in former studies (30-32) to represent more highly phosphorylated variants of protein S6, which is normally phosphorylated to a lesser extent. In aggreement with previous studies on S6 in acute injured livers (40-42) an elevated degree of phosphorylation of this protein was found to be the earliest sign of ribosomal alteration during the development of chronic hepatic damage. The cathodically located satellite-protein of S6 seen in long-term damaged liver ( $\mathrm{c}$ in fig. $2 \mathrm{D}, \mathrm{E}$ ) has not been observed before. It may represent an un-or low phosphorylated portion of S6.

\section{References}

1. Wool, I. G. \& Stöffler, G. (1974), in Ribosomes (Nomura, M., Tissieres, A. \& Lengyel, P., eds.) Cold Spring Habor Laboratory, New York, 417-460.

2. Dice, J. F. \& Schimke, R. T. (1972), J. Biol. Chem. 247, 98-111.

3. Steinert, P. M., Baliga, B. S. \& Munro, H. N. (1974), J. Mol. Biol. 88, 895-911.

4. Vournakis, J. \& Rich, A. (1971), Proc. Nat. Acad. Sci: USA $68,3021-3025$.

5. Kurland, C. G. (1972), Annu. Rev. Biochem. 41, 37ī-408.

6. Mayer, G. \& Schomerus, H. (1975), Digestion 13, 261-271

7. Richter, E., Clauditz, S., Leinweber, B. \& Kühn, H. A. (1968), Acta Hepato-Splenol. 6, 376-381.

8. Rothschild, M. A., Oratz, M. \& Schreiber, S. S. (1973), Gastroenterology 64, 324-337.

9. Barker, E. A., Smuckler, E. A. \& Benditt, E. P. (1963), Lab. Invest. 12, 955-960.
Long-term liver damage induces severe changes of the cellular composition of the organ (43). Therefore, the modified ribosomal proteins in diseased liver might originate from cells other than hepatocytes, e.g. von Kupffer cells, fibroblasts etc.

Qualitatively different changes of the electrophoretic mobility pattern of proteins have been reported for ribosomes from regenerating rat liver $(44,45)$, which were, as in the present study, preferentially localized in the small subunit (44). The electrophoretic patterns of ribosomal proteins from normal liver and hepatoma, however, do not show significant differences $(46,47)$. As yet, no similar studies have been performed on ribosomes from chronically injured liver. Since the functions of individual ribosomal proteins are not known, the meaning of the changes for some specific ribosomal activities are unclear at present.

\section{Acknowledgement}

The expert technical assistance of Mr. Eddy Van de Leur is greatfully acknowledged.

10. Gressner, A. M., Pazen, H. \& Greiling, H. (1977), HoppeSeyler's Z. Physiol. Chem. 358, 825-833.

11. Jeejeebhoy, K. N., Phillips, M. J., Bruce-Robertson, A., Ho, J. \& Sodtke, U. (1972), Biochem. J. 126, 1111-1126.

12. Smuckler, E. A., Iseri, O. A. \& Benditt, E. P. (1961), Biochem. Biophys. Res. Commun. 5, 270-275.

13. Huberman, A. \& Soberon, G. (1970), Clin. Chim. Acta 29, 121-127.

14. McGee, J. O. D., O'Hare, R. P. \& Patrick, R. S: (1973̧), Nature New Biol. 243, 121-123.

15. Gressner, A. M., Pažen, H. \& Greiling, H. (1977), Experientia $33,1290-1292$.

16. Hirayama, C., Kịura, N., Irisa, T. \& Masuya, T. (1968), Clin. Chim. Acta 21, 49-54.

17. Kaltschmidt, E. \& Wittmann, H. G. (1970), Anal. Biochem. $36,401-412$.

18. Martin, T. E. \& Wool, I. G. (1969); J. Mol. Biol. 43, 151-161. 
19. Stirewalt, W. S., Castles, J. J. \& Wool, I. G. (1971), Biochemistry $10,1594-1598$.

20. Kaulenas, M. S. (1971), Anal. Biochem. 41, 126-131.

21. Sherton, C. C. \& Wool, I. G. (1974), Mol. Gen. Genet. 135, 97-112.

22. Lowry, O. H., Rosebrough, N. J., Farr, A. L. \& Randall, R. J. (1951), J. Biol. Chem. 193, 265-275.

23. Ventimiglia, F. A. \& Wool, I. G. (1974), Proc. Nat. Acad. Sci. USA 71, 350-354.

24. Sherton, C. C. \& Wool, I. G. (1972), J. Biol. Chem. 247, 4460-4467.

25. Wool, I. G. \& Stöffler, G. (1976), J. Mol. Biol. 108, 201-218.

26. Gressner, A. M. \& Wool, I. G. (1974), J. Biol. Chem. 249, 6917-6925.

27. Blat, C. \& Loeb, J. E. (1971), FEBS Lett. 18, 124-126.

28. Kabat, D. (1970), Biochemistry 9, 4160-4175.

29. Loeb, J. E. \& Blat, C. (1970), FEBS Lett. 10, 105-108.

30. Gressner, A. M. \& Wool, I. G. (1974), Biochem. Biophys. Res. Commun. 60, 1482-1490.

31. Gressner, A. M. \& Wool, 1. G. (1976), J. Biol. Chem. 251, 1500-1504.

32. Gressner, A. M. \& Wool, I. G. (1976), Nature 259, 148-150.

33. Liew, C.-C. \& Gornall, A. G. (1973), J. Biol. Chem. 248, 977-983.

34. Liew, C.C. \& Gornall, A. G. (1973), Biochem. Soc. Trans. 1, 994-995.

35. Liew, C.-C. \& Yip, C. C. (1974), Proc. Nat. Acad. Sci. USA 71, 2988-2991.
36. Chang, F. N., Navickas, I. J., Chang, C. N. \& Dancis, B. M. (1976), Arch. Biochem. Biophys. 172, 627-633.

37. Goldenberg, C. J. \& Eliceiri, G. L. (1977), Biochim. Biophys. Acta 479, 220-234.

38. Traugh, J. A. \& Sharp, S. B. (1977), J. Biol. Chem. 252, 3738-3744.

39. Vandrey, J. P., Goldenberg, C. J. \& Eliceiri, G. L. (1976), Biochim. Biophys. Acta 432, 104-112.

40. Gressner, A. M. \& Greiling, H. (1978), Exp. Mol. Pathol. 28 , 39-47.

41. Gressner, A. M. \& Greiling, H. (1977), FEBS Lett. 74, $77-81$.

42. Gressner, A. M. \& Greiling, H. (1978), Biochem. Pharmacol. 27, 2495-2498.

43. Hutterer, F., Rubin, E., Singer, E. J. \& Popper, H. (1961), Cancer Res. 21, 206-215.

44. Anderson, W. M., Grundholm, A. \& Sells, B. H. (1975), Biochem. Biophys. Res. Commun. 62, 669-676.

45. Scheinbuks, J., Sypherd, P. S. \& Moldave, K. (1974), Biochem. Biophys. Res. Commun. 61, 322-328.

46. Bielka, H., Stahl, J. \& Welfle, H. (1971), Arch. Geschwulstforsch. 38/2, 109-112.

47. Delaunay, J. \& Schapira, G. (1972), Biochim. Biophys. Acta 259, 243-246.

48. Welfle, H. \& Bielka, H. (1968), Z. Naturforsch. 23b, 690694.

Priv.-Doz. Dr. A. M. Gressner

Abteilung Klinische Chemie und Pathobiochemie der Medizinischen Fakultät der RWTH

Goethestr. 27-29

D-5100 Aachen 
